University of Wollongong

Research Online

Faculty of Social Sciences - Papers (Archive) Faculty of Arts, Social Sciences \& Humanities

$1-1-2017$

Gender and evolutionary theory in workplace health promotion

Erika Bjorklund

University of Gavle

Jan Wright

University of Wollongong, jwright@uow.edu.au

Follow this and additional works at: https://ro.uow.edu.au/sspapers

Part of the Education Commons, and the Social and Behavioral Sciences Commons

Research Online is the open access institutional repository for the University of Wollongong. For further information contact the UOW Library: research-pubs@uow.edu.au 


\title{
Gender and evolutionary theory in workplace health promotion
}

\begin{abstract}
Objective: Ideas from evolutionary theories are increasingly taken up in health promotion. This article seeks to demonstrate how such a trend has the potential to embed essentialist and limiting stereotypes of women and men in health promotion practice. Design: We draw on material gathered for a larger ethnographic study that examined how discourses of health were re-contextualised in four workplace health promotion interventions in Sweden. Method: This study provided the opportunity to investigate how ideas derived from evolutionary theories produced particular constructs of the healthy employee. A Foucauldian notion of governmentality was used to examine the rationalities, truths and techniques that informed what we have called a 'Stone Age' discourse as these contributed to shaping the desires, actions and beliefs of lecturers and participants in the interventions. Results: We focus on one intervention which used the Stone Age discourse as an organising idea to constitute differences in women's and men's health through references to women as gatherers and men as hunters, thereby positioning men as the physical, emotional and mental ideal and women as the problematic and lacking 'other'. Conclusion: The paper concludes by discussing the implications of such ideas about health and gender for interventions aimed at changing behaviour and lifestyles.

Disciplines

Education | Social and Behavioral Sciences

Publication Details

Bjorklund, E. \& Wright, J. (2017). Gender and evolutionary theory in workplace health promotion. Health Education Journal, 76 (8), 893-905.
\end{abstract}




\title{
Gender and evolutionary theory in workplace health promotion
}

Erika Björklund $^{\mathrm{a}}$ and Jan Wright ${ }^{\mathrm{b}}$

Published in Health Education Journal, 76 (8), 893-905. DOI:

10.1177/0017896917722372

${ }^{a}$ Department of Educational Sciences, University of Gävle, Gävle, Sweden

${ }^{b}$ School of Education, Faculty of Social Sciences, University of Wollongong,

Wollongong, Australia

\begin{abstract}
Objective: Ideas from evolutionary theories are increasingly taken up in health promotion. This article seeks to demonstrate how such a trend has the potential to embed essentialist and limiting stereotypes of women and men in health promotion practice.
\end{abstract}

Design: We draw on material gathered for a larger ethnographic study that examined how discourses of health were re-contextualised in four workplace health promotion interventions in Sweden.

Method: This study provided the opportunity to investigate how ideas derived from evolutionary theories produced particular constructs of the healthy employee. A Foucauldian notion of governmentality was utilised to examine the specific rationalities, truths and techniques that informed what we have called a "Stone Age" discourse, as these contributed to shaping the desires, actions and beliefs of lecturers and participants in the interventions.

Results: The second half of the article focuses on one intervention which used the Stone Age discourse as an organising idea to constitute differences in women and men's health through references to women as gatherers and men as hunters, thereby positioning men as the physical, emotional and mental ideal and women as the problematic and lacking "other".

Conclusion: This paper concludes with the implications of such ideas about health and gender for interventions aimed at changing behaviour and lifestyles.

\section{Keywords}

Evolutionary psychology, Evolutionary health promotion, Gender, Governmentality, Discourse analysis, Sex differences, Gender inequalities, Men's health, Masculinity, Evolutionary theory

\section{Corresponding author:}

Erika Björklund, Department of Educational Sciences, University of Gävle, Kungsbäcksvägen 47, 80176 Gävle, Sweden

Email: erika.bjorklund@hig.se 


\section{Introduction}

As in other areas of health, evolutionary theory is gaining currency in the field of health promotion, with some arguing specifically for an "evolutionary health promotion" (Eaton, Strassman, Nesse, et al., 2002). In this article we seek to demonstrate how such a trend has the potential to embed essentialist and limiting stereotypes of women and men in health promotion practice. We do this by first arguing for the potential of evolutionary theory, both in its more academic and popularised versions, to dominate thinking about health and gender; and second, by illustrating how such ideas are re-contextualised in educational practice and interactions in four Swedish workplace health promotion interventions. Specifically, we draw on the concepts of governmentality and bio-power (Foucault, 1988, 1990; Rabinow \& Rose, 2006; Rose, 1999) to examine how gender comes to be constituted in these interventions through the operations of a discourse, which we have called the "Stone Age discourse". We discuss the consequences of these operations for the ways the participants in the interventions were invited to understand themselves in relation to the idea of the good and healthy person.

\section{An Evolutional Approach to Health Promotion}

Despite fierce debate and critique, evolutionary theory, which has its origins in Darwin's ideas about natural selection (Gould, 2002), has had significant impact on the scientific community, resulting in new research programmes with evolutionary approaches (Rose and Rose, 2001; Smith, Borgerhoff Mulder and Hill, 2001). Sociobiology (Wilson, 1975) and evolutionary psychology or EP (Buss, 1995) are the two most prominent (Rose and Rose, 2001). According to these research programmes, the behaviour of all animals, including humans, can be explained by evolution. A more recent evolutionary research programme is evolutionary health promotion (Cordain et al., 2005).

In evolutionary health promotion, evolutionary ideas have been taken up as a way of explaining contemporary trends in modern morbidity and mortality, which are understood as a result of the "discordance between our ancient, genetically determined biology and the nutritional, cultural, and activity patterns of contemporary Western populations" (Cordain et al., 2005: 341). From this perspective, contemporary humans are perceived to still have digestive and metabolic systems as well as physical capacities and needs similar to the huntergatherers of the Stone Age, that is, hominins living during the Paleolithic period (up until about 10,000 years ago) in pre-agricultural societies. This is conceived as presenting a problem for human health in the context of contemporary conditions and lifestyles and is referred to as a genetic-cultural evolutionary divergence, which in turn is perceived to prescribe (healthy) human behaviour. According to Cordain et al. (2005) and Eaton, Strassman, Nesse, et al. (2002; see also Eaton, Cordain and Lindeberg, 2002), health promotion thus needs to adapt and transform into "evolutionary health promotion", and incorporate more of these evolutionary ideas, as exemplified by the more populist claims about "evolutionary well-being" and "paleolithic lifestyle", including ideas about both physical activity and diet, such as the Paleo-diet (see e.g. Cordain, 2002; De Vany, 2010; Eaton and Eaton, 2003). 
Evolutionary theory has, as mentioned previously, almost since its inception been thoroughly problematised and critiqued. From within the field of evolutionary theory, feminist evolutionary psychology (FEP) and feminist sociobiology is critical of the paucity of focus on, and the minimisation of, women in human evolution (Fehr, 2012; Hrdy, 1981; Hubbard, 1983; and see also Sokol-Chang and Fisher, 2013), Critiques have also been concerned with how evolutionary theories, specifically EP and sociobiology, tend to be essentialist, deterministic and androcentric (see e.g. Allen et al., 1975; Fausto-Sterling, 1992; Hoquet, 2010; Kelly, 2014; Rose and Rose, 2001), with political consequences that have the potential to exacerbate social injustices (Higgs and Jones, 2003; Jackson and Rees, 2007; see also Choi, 2001). Jackson and Rees (2007) argue that in the context of the "siren" narratives of human development in evolutionary accounts, "[c]ultural complexity and behavioural diversity are sidelined, becoming irrelevant as the 'universal' elements of human development are revealed" (Jackson and Rees, 2007: 922). This can be seen for instance in popular and highly influential scientific theories such as the huntergatherer theory, in which men are portrayed as hunters and women as gatherers (see for example, Silverman and Eals, 1992; Silverman et al., 2007). A central idea in hunter-gatherer theory is that evolution and selection have favoured a female-male division of labour and that this division is reflected today in women and men's bodies and behaviour. Political consequences can also be seen, for example, in the transformation of evolutionary imperatives into popularised accounts about the nature of women and men, as in John Gray's (1993) popular book Men are from Mars, women are from Venus, which promotes essentialist ideas about women and men drawing on ideas from EP. In research programmes and popular scientific renditions of evolutionary theories and research on humans, women and men's behaviour thus comes to be perceived as determined by their biological sex.

\section{Gender, Health and Workplace Health Promotion}

Drawing on this feminist critique of evolutionary theories, EP and sociobiology, this paper seeks to address questions about how gender comes to be constituted through evolutionary ideas in health promotion. We do this by looking at one area of health promotion that has been criticised for failing to attend to gender issues workplace health promotion. The critique is concerned with workplace health promotion interventions failing to attend to gender issues in the planning and implementation of interventions (see for example Gelb, Pederson and Greaves, 2011, and Östlin et al., 2007), and for not taking into account male privilege and power or patriarchal structures, policies and institutions (Stewart et al., 2010) in their implementation. While gender may be mentioned as a determinant of health (Gelb et al., 2011), there has been little attention to how gender has been expressed or constituted in health interventions (Verdonk, Seesing and Rijk 2010; Östlin et al., 2007), nor the effects of gender relations on participants. This paper will address this gap.

\section{Theoretical Framework}


Evolutionary theories such as EP, sociobiology and evolutionary health promotion posit that human behaviour is biologically determined. The objective in this paper is however not to attempt to falsify or amend any of these theories but rather to explore and problematise how evolutionary ideas may be expressed in the context of workplace health promotion in ways that are dangerous or even damaging. In doing so, we draw on feminist critiques of these evolutionary theories. As mentioned previously, feminist perspectives are being applied to evolutionary theories both from feminist philosophy and science studies (e.g. Fausto-Sterling, 1997 and Rose and Rose, 2001) and from within EP and sociobiology (e.g. Hrdy, 1981; Hubbard, 1983; Fehr, 2012). Within EP there is an ongoing discussion regarding women, gender and sexuality studies in relation to EP. Feminist evolutionary psychologists (FEPs), such as Fehr (2012), are critical of how feminist philosophers and science studies scholars deliver their critique of EP and suggest that feminist philosophy and science studies have had little uptake and little impact on EP due to their lack of engagement beyond their own fields.

In this paper we look at the problem from a perspective rarely taken up in this literature. Drawing on a feminist poststructuralist perspective, employing for our analysis the concepts of bio-power and governmentality, as introduced and developed by Foucault $(1988,1990,2003)$, and developed by Rose (1999; Rabinow and Rose, 2006), we examine how gender is constituted in material contexts/'real life' - through the instruction provided in the context of workplace health interventions. Inherent to the notions of governmentality and bio-power is the idea that discourses govern how it is possible to think and act. From this standpoint then, talk and discourses are not perceived as innocent or "mere" talk (Hall, 2001) but as governing the production, regulation and representation of both bodies and subjects through the acquisition of specific dispositions, tastes and abilities (Foucault, 1988; Rose, 1999). Thus, discourses drawn on in health promotion interventions, govern how it is possible to think and act about our-selves and others in relation to health, and by extension have material effects on, in this case, women and men's health.

\section{The Study}

The paper draws on data gathered for a larger study that examined how discourses of health were contextualised in educational practice and interactions between lecturers and participants in four workplace health promotion interventions in Sweden (see Björklund, 2008). The interventions were initially selected for the original study on the basis of the following criteria: i) a focus on physical activity and/or diet; and ii) interventions that include face-to-face interaction between lecturers and participants which could be documented. The first criterion was prompted by a notion that bringing otherwise private issues of physical activity and eating into the gaze of the employer is problematic (see for example Björklund, 2008; Holmqvist and Maravelias, 2006; Allender, Colquhoun and Kelly, 2006). The second criterion was due to the study's interest in interaction. At the time of the study and in the region, the four interventions selected for the study were the only ones found that met these criteria. The interventions were all implemented at worksites in mid-sized towns in Sweden: one a university; one for local government; and two industry-sites (see appendix for details). The interventions had between 12- 
16 participants, except for Intervention 3, one of the industry-site interventions, which had approximately 900 participants. In interventions 1 and 4, all participants were women, while interventions 2 and 3 , which were the industry-sites, were both women and men, with a majority of men participating.

For the larger study ethnographic data was collected by Björklund (2008) through: interviews with participants and lecturers; observations of interactions between lecturers and participants, documented as field notes; and materials used in the interventions as course literature. The close reading and rereading of the data for the larger study, pointed to a recurrent and conspicuous use of language introduced by the lecturers and in some of the written materials that drew on evolutionary ideas in their constructions of notions of health and, in one intervention in particular, the close association between these and the construction of gender. This caused us to question how these evolutionary ideas operated in the interventions, how the engagement with these ideas played out in the interventions and with what effects. Hence, although the interest in the larger study was with the interactions between lecturers and participants, for the present article, the focus was on the lectures (documented as field notes) and the written materials (course literature).

The lectures and written materials were then subjected to a discourse analysis (Hall, 2001), in which all instances of an evolutionary discourse were identified based on specific inflections linking health to human evolution. The extent to which this discourse was drawn upon in the interventions varied from a modest appearance in interventions 1, 2 and 4, to a more prominent presence in intervention 3. However, from a discourse theory and governmentality point of view, it is not necessarily, and not for the purposes of this paper, the prominence of a discourse that is of interest, but rather how the discourse operates and what it does in terms of governing how intervention participants are invited to think and act.

Following Foucault $(1988,1990,2003)$, Rose (1999) and Rabinow and Rose (2006), a governmentality lens was then invoked whereby we formulated a set of questions to guide our analysis of how the evolutionary discourse operated in the interventions and with what "effects". The questions we formulated were: How were notions of human evolution drawn on in the interventions; what subjectivities were produced in conjunction with notions of human evolution and with what effects for how participants were invited to understand themselves as (un)healthy employees; by what means was the subjectivity proper to these notions of human evolution infused into people; why was no one protesting; what authorities were drawn on to render the discourse reasonable? The material was then reread and analyzed with these questions in mind.

In the following sections, these questions are addressed, beginning with a general indication of how (un)healthy subjects were constituted across all of the interventions and then moving to a focus on Intervention 3 to explore how the discourse operated to produce particular forms of gendered subjectivities.

\section{Findings}

\section{Constituting the (Evolutionary) Healthy Subject}


Ideas derived from evolutionary health promotion as well as evolutionary psychology and sociobiology were evident in the presentations and materials of all four interventions to varying degrees with subsequent different "effects" for the ways the gendered healthy subject was constituted. We have called the particular translations or re-contextualisations of the evolutionary health discourses the Stone Age discourse because it involved the explicit description of people as Stone Age humans, the attribution of preferences and predilections to human genetics and the claim that humans are the same "biological creatures" today as they were 10,000 years ago.

In all of the interventions this discourse was used to attribute a diet high in fat and/or carbohydrates (or rather, sugar) and a sedentary lifestyle to contemporary health problems. It was called on to explain undesirable healthrelated lifestyle habits and to provide arguments for the desired ones. For example, in interventions 1, 2 and 4, ideas from evolutionary nutrition were evident in explanations for preferences for fatty, salty and sweet foods:

We often choose sweet and fatty foods. This is not because of a flawed character but is due to a predilection for chocolate, Snickers and such. The sweetness signals that it's carbohydrates and non-poisonous. (Intervention 1)

The evolutionary theory of the "thrifty gene" (see Neel, Weder and Julius, 1998) was evident in explanations of why we might store fat - a condition that it was argued does not serve us well today (Interventions 3 and 4). The following quote comes from the textbook, which formed the basic reading for Intervention 4:

We have forgotten that we basically are the same biological creatures today as we were when we ran around hunting with a stone axe 10,000 years ago. We lead a mobile and active life in nature; our bodies are built for it. Sometimes there was an abundance of food, and long periods food was scarce. That's why we have the capacity to store fat in our body tissues, a sort of built in reserve pantry to use when in a pinch. (Kihlman, 2003: 4, translated from Swedish)

As elements of a Stone Age discourse, these ideas provided the presenters with "scientific" explanations as to why the participants need to be physically active and why they are likely to put on too much weight. It also allowed the presenters to frame behaviours, which from a contemporary health perspective are irrational or at the very least unhealthy, as "normal" or at least understandable. In this context such constructions, we argue, serve to alleviate the shame (of being overweight and/or engaging in the behaviours being criticised), thereby avoiding alienating the participants and encouraging continued participation.

References were also made to "hunting with a stone axe". In Intervention 4 this reference was made in the course book and in Intervention 2 it was a cartoon illustration of "the hunter" in a lecture on the importance of physical activity. In the illustration, the hunter was depicted as male, suggesting a deterministic gender construction. In the Nordic countries, although both women and men hunt, hunting is more often associated with male experience (Lindberg, 2010) and anthropological 
descriptions of the Stone Ages tend to place the axe in the hands of men (see for example Kuhn and Stiner, 2006). While notions of femininity and masculinity thus were implicitly reproduced in most of the studied interventions, in contrast, in Intervention 3 a Stone Age discourse was much more explicitly enjoined to explain gender differences in health behaviours and outcomes and it is on this Intervention that we now focus.

\section{Establishing authority and available gendered subject positions}

The main purpose of the follow-up lecture in Intervention 3 (see appendix) was to inspire the participants to continue the health work they had started in the previous year. The male lecturer established his authority by presenting his educational background in the field of health promotion as a physical therapist and the founder of a corporate health service provider. The podium was stacked with books, which the lecturer regularly gestured towards as support for his arguments. In addition, he made general references to "research" to support his claims about health and gender and to widespread popular knowledge when he was claiming something to be true about women and men. The following quote is an example of the lecturer using the imprimatur of research to argue that women lose weight by managing their intake of protein through a vegetarian diet: "Women have been found to feel better if they eat [their protein in the form of] beans and vegetables, especially if they want to lose weight". The claim, "women have been found to", is not attributed to any source, but the wording suggests without explicitly saying so, that the claim has a scientific basis, giving it more credibility.

Besides drawing on research, readings and his own background for authority, the presenter used humour in his lecture, which functioned as a technology to make his ideas both palatable and more difficult to contest. For instance, he began the lecture by summarising the participants' results, based on baseline and follow-up health profile assessments. These results demonstrated a much better success rate in achieving programme outcomes for the men as compared to the women in the programme. The lecturer also commented that the programme had received a critique from some participants as being "a bit manly". To this critique he responded by explaining women's poorer results in terms of inherent female attributes. This then became a theme in the lecture, with many elaborations, intended to be humorous, to make the point that it was due to the women's intrinsic biological nature that they were destined to fail. He explained the men's greater success in achieving health outcomes as a result of the male participants' more "natural" predisposition to benefit from the programme. Specifically, the differences in health outcomes were attributed to women and men's respective histories as gatherers and hunters:

What did we do when we lived in the caves? What did men do? They hunted. What did women do? Collected herbs and beans. And this is still going on when we make decisions today.

This quote demonstrates how from the very beginning of the presentation, the lecturer drew on the Stone Age discourse to position women and men differently 
in relation to the intervention. In doing so, as the following will show, men were positioned as "good" participants, compliant and successful; and women were positioned as "bad" participants, problematic, difficult and failing. From this perspective the genetically determined division of labour between men and women was responsible for female and male physiology, behaviours, habits and preferences. The lecturer addressed the audience as if they already shared his ideas about women and men being determinedly different. Given the predominance of men in the audience and that they were portrayed in such a positive way, it was likely that they would agree with his account.

\section{Gendering the Healthy (Evolutionary) Subject}

Throughout the lecture in intervention 3, drawing on the hunter-gatherer theory, the presenter explained women and men's biology as inextricably linked to their differing social roles, though the reasoning behind this was not always clear. In the quote below the presenter explains how because women are gatherers they have a hormone that predisposes them to "gather" fat on their breasts, rear and thighs:

Women collect nuts and berries and they have a hormone that collects. ... the estrogen in women is, besides for ovulating, also used to collect fat. It is accumulated in the breasts, the rear and the thighs. Women's bodies are programmed to gather fat.

On one hand women's capacity to hoard fat is described as an evolutionary advantage. On the other, in the context of an intervention designed to enhance health, it was also construed as a distinct disadvantage. For example, the physiological location of fat on women's bodies was described as more difficult to "get at" and reduce. Thus, women's biological nature positioned women at a disadvantage for weight loss from the start, giving them a harder time losing weight and "succeeding" in the intervention.

The phenomenon of women as gatherers, with a "collecting hormone" (oestrogen) was also described as predisposing women to gathering behaviour in general, such as gathering various belongings in a handbag: "Women always carry a bag for storing/gathering stuff"; and as predisposing them to multitasking and to being more exploratory in relation to food compared to men. In the context of the intervention, these "evolutionary traits" were construed as problems that got in the way of women's success: women were unable to focus; were impulsive in their dietary choices; and not compliant with the intervention goals. The following quotes illustrate how women's dietary and other daily practices were compared to those of men, who were described as focused and compliant with programme goals:

How do women eat? One week they will have oatmeal, the next it is muesli and milk, then it is cottage cheese and pineapple (the lecturer moves around across the podium as if the different food items were scattered at different places and needed to be gathered together).... What is the difference between men and women in almost everything? Women try different things. Why are they like that? They were gatherers. 
Men have a tendency to do one thing at a time. Have you thought about that? They do not knit, iron, plan tomorrow's lunch [all at the same time]. Women often tire of doing things in one way all of the time. This we have seen is a problem in our programme, because here you have to do it in one way.

Women were thus characterised as not only disadvantaged by their physiological makeup (hoarding fat) but also by their mental and emotional dispositions. Women's impulsiveness was perceived to make women unlikely to be able to follow the intervention's dietary schedule, positioning women as difficult intervention participants, who were, at the same time, also in dire need of intervention because of their impulsive nature and bodies prone to gather and retain fat.

In comparison to the women in the intervention, the male participants' success in the programme was attributed to bodies that had great potential and aptitude for health, both due to their physicality and to men's character. At the same time their sedentary nature was confusingly construed as both normal and abnormal behaviour; nonetheless it was described as undesirable behaviour. Drawing on the notion of "man as hunter", the human body was depicted as built for movement and the physically active person was positioned as the ideal. For their Swedish audience the legitimacy and appeal of this idea was likely to be enhanced by their resonance with popular historical Nordic ideas romanticising both hunting and nature (Hörnsten, 2000). The hunter was primarily depicted as male, with a lean, muscular physique, stamina and explosiveness. Unlike women, their body-fat was described by the lecturer as dispersed in muscle tissue, "like tenderloin" which, together with male testosterone, predisposed men to effectively burn fat. Although changing sedentary behaviour might take discipline, for men then, weight loss should be easy: "A man who stabilises his blood sugar and takes walks, he will lose weight". While, on the one hand, the normative construction of men as more able to lose weight would seem to be a positive attribution, on the other, this places further pressure on overweight men to quickly lose weight. It also made the whole idea of overweight men problematic: if it is that easy, then no man should have to be overweight.

As "hunters", men were assumed to prefer meat and animal protein; a nutrient described as particularly beneficial for men to improve their wellbeing. At the same time, men were described as being satisfied with eating the same thing every day. This was explained by reference to the single-mindedness and focus required to be a good hunter:

If a man has decided to lose weight, then he goes at it with some force. He follows the programme. ... We men are hunters, and are supposed to take down prey ... . When men are taking down prey, or when they're watching sports on TV, then they are one with the TV. If the wife comes and tries to talk to you, then you can't hear her.

A man does one thing at a time. ....What about women? How many women eat three slices of loaf and drinks chocolate-milk for breakfast for 43 years, 52 weeks a year, every day? ... Why are we [men] so different? What did men 
do in the caves? They hunted. If they [ate] like women do [meaning trying this then that]; there is an elk, a deer, and a fish [he moves around across the podium, illustrating indecisiveness], what would happen? ... How many elks would you shoot if you didn't [stay calm and still]? We men do one thing at a time.

The regular and repeated consumption of bread and milk in this quote was not a dietary recommendation but rather served to highlight men's ability to stick to one type of diet. Since being able to stick to a plan and focus on one thing at a time were things that the participants were told were important to be able to achieve success in the intervention programme, the above quote positions men as very adept intervention participants. At the same time men's nature in these quotes is not always depicted as attractive; men are characterised as focused but also inattentive and insensitive to their partners as well as boring eaters.

The male higher level of testosterone, in the following quote attributed to their participation in the programme, also led to further expectations of how men should behave and feel:

Men have more testosterone and $5 \%$ more muscle-mass than women. ... What does testosterone do? What do you do when you feel heavy with testosterone? Heavy in the groin? If you're in the mood, then you're in the mood! You trap the prey now! Assertively but lovingly. Hopefully you have more testosterone now [as a result of participating in the programme].

In this manner, the contemporary male hunter was described as endowed with sexual urges. By conflating hunting and sex, the notion of male prowess borders on glorifying sexual assault. Furthermore, the expectation conveyed was that the male participants who had been in the programme for a year and who had followed the programme should expect to experience a stronger sex drive.

The ideal of the male hunter also has a subtext. It suggests that failure to succeed in the intervention indicates a deficiency of those natural attributes that constitute what it means to be male, a deficiency of 'normal' masculinity. While the attribution of easy weight loss, physical aggression and sexual success might be heartening for some men, for those who do not measure up, it signals their failure not only in the intervention but as men. At the same time, at this point in the intervention, the beginning of the second year, they still had a chance of success and to thereby re-appropriate their maleness, since increasing their levels of physical activity (and thereby conforming to the interventions injunctions) would aid them in increasing their testosterone.

\section{Discussion}

In a research context in which the expression and constitution of gender in health interventions is not widely explored (Verdonk, Seesing and Rijk, 2010; Östlin et al., 2007), this study offers insights into the potential effects of a form of workplace health promotion which draws on a Stone Age discourse informed by ideas from evolutionary theories such as evolutionary health promotion, EP and sociobiology. It 
demonstrates how evolutionary ideas lend themselves to particular constitutions of gender and draws attention to the effects that these expressions of gender may have on participants' understandings of themselves as (un)healthy subjects.

The analysis of the discourse in Interventions 1, 2 and 4 suggest that a Stone Age discourse need not necessarily be associated with notions about gender. However and in line with other feminist critique (see e.g. Allen et al., 1975; Hoquet, 2010; Kelly, 2014; Rose and Rose, 2001), the analysis of the lecture in Intervention 3 illustrates how the Stone Age discourse risks reproducing an essentialist, deterministic and androcentric notion of gender that is potentially limiting, damaging and denigrating for both women and men. On the one hand, the Stone Age discourse in this context positioned women as inferior and problematic, resonating with Birke's assertion that biomedical practices in general have been "notoriously negative in its descriptions of women's bodies" (Birke, 2003: 43). On the other, although men were attributed with a hunter's nature, which supposedly optimised them as participants in the intervention, it also served to construe them as either a potentially rather unpleasant healthy man or as unhealthy and a failure for not measuring up.

The re-citation of the evolutionary ideas of sex differences, such as evident in the Stone Age discourse in Intervention 3, fosters the status quo of gender relations by explaining gender differences in apparently scientific terms (see also Åsberg and Birke, 2010). Such biologistic ideas are problematic and detrimental to health promotion efforts on a number of counts. Through their inherent determinism, they risk fostering docile subjects who cannot imagine any possibilities for changing their circumstances or ironically their behaviours. They focus on particular essentialised forms of masculinity that accord with hegemonic masculinities that are associated with poor health practices and with power relations that are inimical to both women and men's health. These run counter to the message of increasing numbers of studies and recommendations in relation to promoting men's health (for example Jackson and Rees, 2007; Misan and Oosterbroek, 2014) which recognise the diversity amongst groups of men and the importance of taking into account the social and cultural contexts "in which men live and experience health and illness" (Misan and Oosterbroek, 2014: 9). Many advocate a gender equity approach rather than one that further divides women and men or "perpetuates notions of a hegemonic masculinity, stereotypical archetypes or the ideology that 'blames men' for risk taking and seeming health indifference" (Misan and Oosterbroek, 2014: 9).

We would also argue that it was no coincidence that this gendered rendition of the Stone Age discourse became the framing idea for health promotion in Intervention 3. The site for this intervention was an industry (the lumber industry) in which men far outnumber women and in the intervention the men dominated the numbers by approximately 17 to one. In other words the male lecturer was faced with the need to engage men whom might otherwise have been reluctant participants (see Creighton and Oliffe, 2010; Gough, 2006 and 2013; Mallyon et al., 2010; Galdas, Cheater and Marshall, 2005 on men's reluctance to admit to health issues or consult a health professional). We suggest that he chose to engage his male audience through building solidarity with the men against and, at the expense of, the 'other', the female participants and by drawing on hegemonic notions of masculinity and femininity that privileged the male participants (as hunters and sexual 
predators). For example, he ignored feedback that his approach was "too manly" and instead redirected the critique to explain the women's poor performance in the intervention. In this intervention, the Stone Age discourse was put to work to appeal to the male audience, to seduce them and catch their interest, and to persuade them to listen and comply with injunctions to engage in practices that would improve their health.

\section{Conclusion}

Evolutionary theories, EP and sociobiology have been scrutinised and problematised by feminists within philosophy and science studies as well as by feminist EP (Allen et al., 1975; Choi, 2001; Fehr, 2012; Hoquet, 2010; Hrdy, 1981; Hubbard, 1983; Jackson and Rees, 2007; Rose and Rose, 2001; Sokol-Chang and Fisher, 2013). This study makes a contribution to these fields by bringing the critique to bear on practice and also to the field of evolutionary health promotion. In the context of calls for more attention to health promotion that is specifically targeted to men and which specifically moves away from approaches that draw on hegemonic constructions of masculinity (Smith, 2007; Jackson and Rees, 2007), and in the context of calls for more attention to EP (Fehr, 2012), we suggest that more critical research is needed which examines how messages about masculinity play out in specific health promotion interventions beyond those conducted in the media (see for example, Jackson and Rees, 2007), especially where they target men and especially as they engage with evolutionary ideas. Many of these are likely to be in workplace settings. An increasing prominence of evolutionary health promotion is likely to shape such interventions in ways that may be counterproductive in terms of addressing the complexity of men's health issues and the importance of social and cultural contexts in shaping these. This same could be said for women.

This study makes a contribution to that knowledge but we acknowledge that it is limited by its focus on the Swedish context. However, as the influence of evolutionary ideas shape health promotion, more research is required to examine its effects. With Jackson and Rees (2007: 927), we argue that as sociologists and health educators we are failing the public if we do not engage with "simplified evolutionary accounts of human nature [that] are accepted as accurate simply because they are 'scientific'". We argue that we also need to engage with the "effects" of such accounts when they are re-cited in practices such as those of the health promotion interventions described in this paper. We need to make visible their modes of operation in terms of the subject positions they produce, the authority on which they draw and their subsequent effects on how participants come to regard themselves as (un)healthy subjects and make choices about how they live their lives. Furthermore, to reiterate what was pointed out earlier about the paucity of gender perspectives in health intervention practice (see e.g. Gelb, Pederson and Greaves, 2011; Östlin et al., 2007; Stewart et al., 2010; Verdonk, Seesing and Rijk 2010) , a more critical and gender-aware stance needs to be adopted in the planning and implementation of health interventions, or such disregard can be expected to compromise the potentially positive effects of health promotion initiatives for both women and men. 


\section{References}

Allen E, Beckwith B, Beckwith J, Chorover S, Culver D, et al. (1975) Against "Sociobiology". The New York Review of Books, 7 August 1975.

Allender S, Colquhoun D and Kelly P (2006) Governing the working population through workplace health: Knowledge, self and power in workplace health programs. Critical Public Health 16(2): 131-142.

Åsberg C and Birke L (2010) Biology is a feminist issue: interview with Lynda Birke. European Journal of Women's Studies November 17(4): 413-423.

Birke L (2003) Shaping biology: feminism and the idea of the biological. In: William SJ, Birke L and Bendelow GA (Eds) Debating Biology: Sociological reflections on health, medicine and society. London: Routledge, pp. 39-52.

Björklund E (2008) Constructing the healthy employee? Governing gendered subjects in workplace health promotion. PhD Thesis, University of Umeå, Sweden.

Buss D (1995) Evolutionary Psychology. A new paradigm for psychological science. Journal of Social, Evolutionary, and Cultural Psychology 7(4): 295-296.

Choi PL (2001) Genes and gender roles: Why is the nature argument so appealing? Psychology, Evolution \& Gender 3(3): 279-285.

Cordain L (2002) The Paleo diet: Lose weight and get healthy by eating the food you were designed to eat. New York: JohnWiley \& Sons, Inc.

Cordain L, Eaton SB, Sebastian A, et al. (2005) Origins and evolution of the Western Diet: health implications for the $21^{\text {st }}$ century. American Journal of Clinical Nutrition 81(2): 341-354.

Creighton G and Oliffe JL (2010) Theorising masculinities and men's health: A brief history with a view to practice. Health Sociology Review 19(4): 409-418.

De Vany A (2010) The new evolution diet: What our Paleolithic ancestors can teach us about weight loss, fitness, and aging. New York: Rodale.

Eaton SB, Cordain L and Lindeberg S (2002) Evolutionary health promotion: a consideration of common counterarguments. Preventive Medicine 34(2): 119-123.

Eaton SB and Eaton SB (2003) An evolutionary perspective on human physical activity: Implications for health. Comparative Biochemistry and Physiology Part A, 136(1): 153-159.

Eaton SB, Strassman BI, Nesse RM et al. (2002) Evolutionary health promotion. Preventive Medicine 34(2): 109-118. 
Fausto-Sterling A (1992) Myths of Gender: Biological Theories about Women and Men. New York: Basic Books.

Fehr C (2012) Feminist Engagement with Evolutionary Psychology. Hypatia 27(1): 5072.

Foucault M (1988) Technologies of the Self. In: Martin LH, Gutman H and Hutton PH (Eds) Technologies of the self. The University of Massachusetts Press, pp. 16-49.

Foucault M (1990) The Will to Knowledge (Vol. 1, The History of Sexuality). Harmondsworth: Penguin Books.

Foucault M (2003) Governmentality. In: Rabinow P and Rose N (Eds) The Essential Foucault. New York: The New Press, pp.229-245.

Galdas P, Cheater F and Marshall P (2005) Men and health help-seeking behaviour: literature review. Journal of Advanced Nursing 49(6): 616-623.

Gelb K, Pederson A and Greaves L (2011) How have health promotion frameworks considered gender? Health Promotion International 27: 445-452.

Gough B (2006) Try to be healthy, but don't forgo your masculinity: Deconstructing men's health discourse in the media. Social Science \& Medicine 63(9): 2476-2488.

Gough B (2013) The psychology of men's health: maximizing masculine capital. Health Psychology 32(1):1-4.

Gould SJ (2002) The Structure of Evolutionary Theory. Belknap: Harvard University Press.

Gray J (1993) Men are from Mars, women are from Venus. New York: Harper Collins Publishers.

Hall S (2001) Foucault: Power, knowledge and discourse. In: Whetherell M, Taylor S and Yates SJ (Eds) Discourse Theory and Practice. London: SAGE, pp.72-81.

Higgs P and Jones IR (2003) Ultra-Darwinism and health: the limits of evolutionary psychology. In: William SJ, Birke L and Bendelow GA (Eds) Debating Biology: Sociological reflections on health, medicine and society. London: Routledge, pp.2738.

Holmqvist M and Maravelias C (2006) Hälsans styrning av arbetet. Lund: Studentlitteratur.

Hoquet T (2010) Is Sociobiology Amendable? Feminist and Darwinian women biologists confront the paradigm of sexual selection. Diogenes 57(1): 113-126. 
Hörnsten L (2000) Outdoor recreation in Swedish forests - implications for society and forestry. PhD thesis, Swedish University of Agricultural Sciences, Sweden.

Hrdy SB (1981) The Woman That Never Evolved. Cambridge: Harvard UP.

Hubbard R (1983) Have Only Men Evolved? in S Harding and MB Hintikka (eds) Discovering Reality. Dordrecht: Reidel, pp. 45-69.

Jackson A and Rees S (2007) The Appalling Appeal of Nature: The Popular Influence of Evolutionary Psychology as a Problem for Sociology. Sociology 41(5): 917-930.

Kelly S (2014) Tofu feminism: can feminist theory absorb evolutionary psychology? Dialectical Antropology 38(3): 287-304.

Kihlman I (2003) Livet är ditt! - om kost och motion, stress och motivation, Hälsoskola. ABF Förbundsexpeditionen.

Kuhn SL and Stiner MC (2006) What's a mother to do? The division of labor among neandertals and modern humans in Eurasia. Current Anthropology 47(6): 953-981.

Lindberg E (2010) Hunter demography, trends and correlates of hunting participation in Sweden. Master's thesis, Swedish University of Agricultural Sciences, Sweden.

Mallyon A, Holmes M, Coveney J et al. (2010) I'm not dieting, 'I'm doing it for science': Masculinities and the experience of dieting. Health Sociology Review 19(3): 330-342.

Misan G and Oosterbroek C (2014) Practitioners' Guide to Effective Men's Health Messaging. Men's Health Resource Kit 2, Penrith, MHIRC, University of Western Sydney.

Neel JV, Weder AB and Julius S (1998) Type II diabetes, essential hyper-tension, and obesity as 'syndromes of impaired genetic homeostasis': the 'thrifty genotype' hypothesis enters the 21st century. Perspectives in Biology and Medicine 42(1): 4474.

Östlin P, Eckermann E, Mishra US, et al. (2007) Gender and health promotion: a multisectoral policy approach. Health Promotion International, 21(S1): 25-35.

Rabinow P and Rose N (2006) Biopower today. BioSocieties 1(2): 195-217.

Rose $\mathrm{H}$ and Rose S (2001) Alas, poor Darwin. Arguments against evolutionary psychology. London: Vintage.

Rose N (1999) Powers of freedom. Cambridge: Cambridge University Press. 
Silverman I and Eals M (1992) Sex Differences in Spatial Abilities: Evolutionary Theory and Data. New York: Oxford Press.

Silverman I, Choi J and Peters M (2007) The Hunter-Gatherer Theory of Sex Differences in Spatial Abilities: Data from 40 Countries. Archives of Sexual Behavior, 36(2): 261-268.

Smith EA, Borgerhoff Mulder M and Hill K (2001) Controversies in the evolutionary social sciences: a guide for the perplexed. Trends in Ecology \& Evolution 16(3): 128135.

Smith JA (2007) Beyond masculine stereotypes: Moving men's health promotion forward in Australia. Health Promotion Journal of Australia 18(1): 20-25.

Sokol-Chang R and Fisher ML (2013) Letter of purpose of the feminist evolutionary psychology society. Journal of Social, Evolutionary, and Cultural Psychology 7(4): 286294.

Stewart A, Lewis K, Neophytou K, et al. (2010) Does combining health promotion and feminist frameworks equal better health outcomes for women? Paper presented at the $6^{\text {th }}$ Australian Womens Health Conference in Hobart, Tasmania, 20 May 2010. Retrieved from http://conference.awhn.org.au/downloads/0189_KoulaNeophytou.pdf

Verdonk P, Seesing H and De Rijk A (2010) Doing masculinity, not doing health? A qualitative study among Dutch male employees about health beliefs and workplace physical activity. BMC Public Health 10: 712.

Wilson EO (1975) Sociobiology: The New Synthesis. Cambridge: Harvard University Press. 


\section{Appendix}

\begin{tabular}{|c|c|c|c|c|}
\hline \multicolumn{5}{|c|}{ Intervention specifics } \\
\hline & Intervention 1 & Intervention 2 & Intervention 3 & Intervention 4 \\
\hline Workplaces & $\begin{array}{l}\text { University (600 } \\
\text { employees) }\end{array}$ & $\begin{array}{l}\text { Steel industry } \\
\text { (6000 local } \\
\text { employees) }\end{array}$ & $\begin{array}{l}\text { Lumber/pulp } \\
\text { industry (1200 } \\
\text { employees) }\end{array}$ & $\begin{array}{l}\text { Local } \\
\text { government } \\
(2300 \\
\text { employees })\end{array}$ \\
\hline Participants & 16 women & $\begin{array}{l}4 \text { women, } 8 \\
\text { men }\end{array}$ & $\begin{array}{l}\text { Approx. } 50 \\
\text { women, } \\
850 \text { men }\end{array}$ & 12 women \\
\hline $\begin{array}{l}\text { Number of } \\
\text { sessions in the } \\
\text { interventions }\end{array}$ & $\begin{array}{l}\text { Eight 1-2 hour } \\
\text { sessions } \\
\text { (weekly) }\end{array}$ & $\begin{array}{l}25 \text { whole-day } \\
\text { sessions } \\
\text { (weekly) } \\
+ \text { two health } \\
\text { profile } \\
\text { assessments }\end{array}$ & $\begin{array}{l}\text { Two } 1 \text { hour } \\
\text { lectures one } \\
\text { year apart, each } \\
\text { repeated nine } \\
\text { times to } \\
\text { accommodate } \\
\text { all employees } \\
+ \text { three health } \\
\text { profile } \\
\text { assessments } \\
\text { per employee + } \\
\text { one lecture for } \\
\text { family } \\
\text { members }\end{array}$ & $\begin{array}{l}\text { Nine } 2 \text { hour } \\
\text { sessions } \\
\text { (fortnightly) }\end{array}$ \\
\hline \multicolumn{5}{|c|}{ Empirical material used for this paper } \\
\hline Observations & 10 hours & Last 50 hours & $\begin{array}{l}9 \text { hours } \\
\text { (second lecture } \\
\text { repeated nine } \\
\text { times) }\end{array}$ & First 6 hours \\
\hline $\begin{array}{l}\text { Other } \\
\text { material }\end{array}$ & $\begin{array}{l}\text { Hand-outs, } \\
\text { overheads }\end{array}$ & $\begin{array}{l}\text { Hand-outs, } \\
\text { overheads, } \\
\text { written } \\
\text { assignments }\end{array}$ & $\begin{array}{l}\text { Magazine } \\
\text { articles, } \\
\text { posters, } \\
\text { advertisement } \\
\text { brochures }\end{array}$ & $\begin{array}{l}\text { Course book, } \\
\text { hand-outs }\end{array}$ \\
\hline
\end{tabular}

Intervention specifics and empirical material. 